\section{CITAÇÃO}

Santos, J. M. B. L., Peres, N. (2018)

Biblioteca Nacional de Singapura,

Rev. Ciência Elem., V6(03):065.

doi.org/10.24927/rce2018.065

\section{EDITOR}

José Ferreira Gomes,

Universidade do Porto

\section{EDITOR CONVIDADO}

João Lopes dos Santos,

Universidade do Porto

\section{RECEBIDO EM}

21 de setembro de 2018

\section{ACEITE EM}

21 de setembro de 2018

\section{PUBLICADO EM}

04 de outubro de 2018

\section{COPYRIGHT}

(C) Casa das Ciências 2018.

Este artigo é de acesso livre, distribuído sob licença Creative Commons com a designação CC-BY-NC-SA 4.0, que permite a utilização e a partilha para fins não comerciais, desde que citado o autor e a fonte original do artigo.

\title{
Biblioteca Nacional de Singapura
}

in imagem.casadasciencias.org

Visitei a Biblioteca Nacional de Singapura com o Nuno em agosto de 2013. 0 edifício icónico de 16 andares, foi desenhado pelo arquiteto Malaio Ken Yeang com uma preocupação de sustentabilidade ambiental. Entrámos para uma enorme Plaza ao nível da rua, fugindo do calor húmido sufocante que envolve Singapura nas suas quatro estações: Verão, Verão, Verão e Verão. Enquanto eu gozava o alívio proporcionado pela frescura da Plaza, reparei no Nuno, numa posição estranha, torcido como uma hélice, a apontar a câmara para o topo do edifício. Ele vira o que eu não vi!

João Lopes dos Santos

Universidade do Porto
De tons originais esverdeados, a fotografia a preto e branco realça aspetos como a reflexão da luz, o contraste entre o claro e o escuro, a textura entre a zona espelhada, completamente plana, e as paredes laterais com elementos mais ou menos salientes. As linhas perfeitas na zona espelhada guiam o olho para um infinito que realmente não existe. A este efeito acresce um sentido de horizontalidade da estrutura, quando, efetivamente, a fotografia foi obtida na vertical, de baixo para cima. Assim, o olhar foge para a parte mais longínqua da imagem, para algo que sugere uma janela quando, efetivamente, é uma abóboda envidraçada de geometria plana. As aberturas laterais deixam entrar imagens adicionais, vistas em reflexão, de um exterior que se pode imaginar mas que é, ao mesmo tempo, misterioso e inatingível.

Nuno Peres

Universidade do Minho

rce.casadasciencias.org

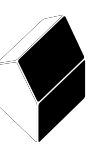




\section{REVISTA DE CIÊNCIA ELEMENTAR}

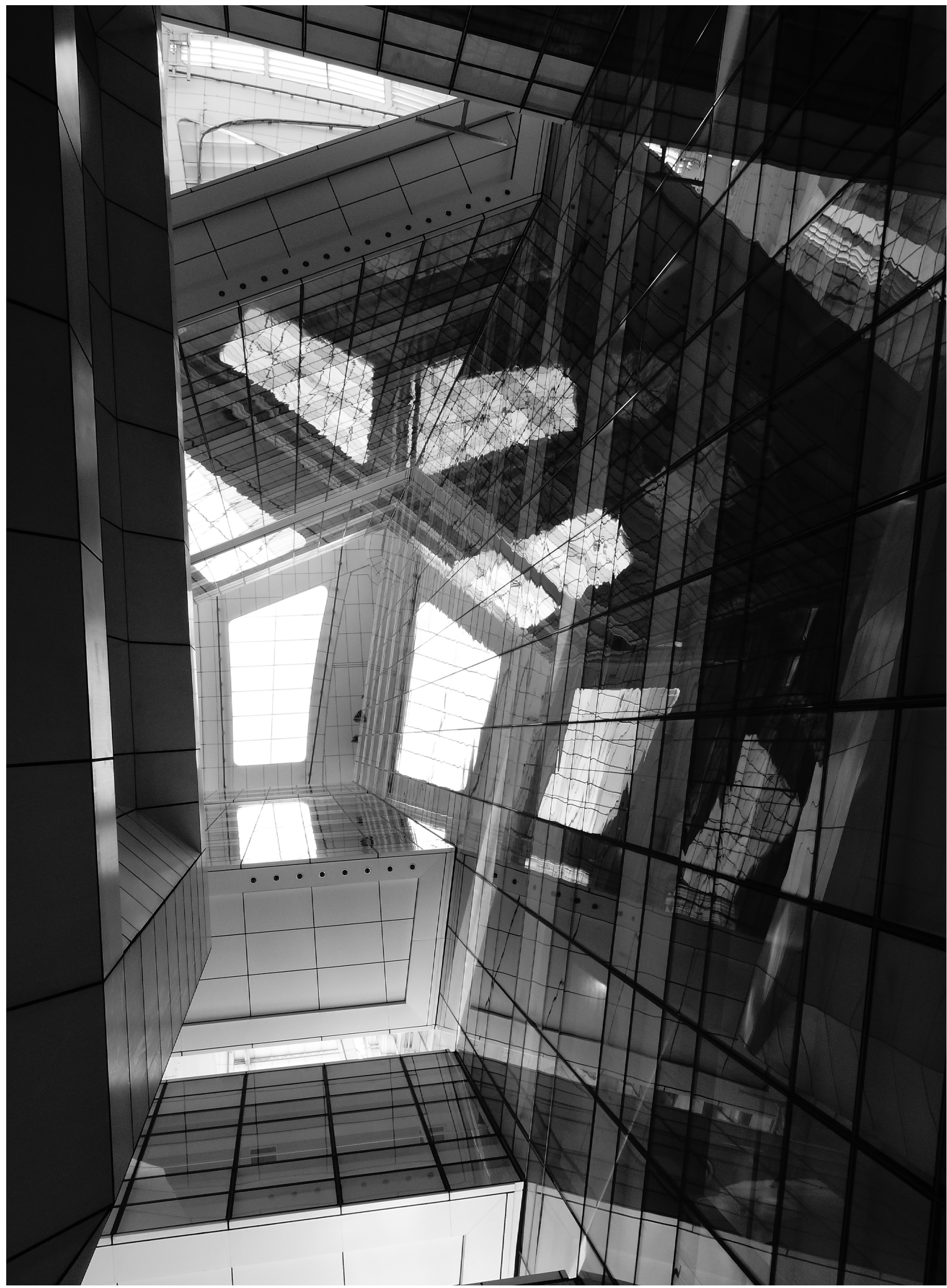

